\title{
大区画戋場整備事業に伴う換地の 合意形成とその要因
}

\author{
The Agreement on the Replotting Disposition Accompanied \\ with the Land Consolidation Project \\ for Making Large Land Parcels and the Factors that Affect It
}

\section{能 美 誠* \\ Makoto NoHMI}

\section{I はじめに}

現在, 固場整備事業は大区画化による労働生産 性の向上がその主要課題となっているが，その目 的を典型的に追求しようとする事業に，「低コス 卜化水田農業大区画ほ場整備事業」(以下, 大区 画圃場整備事業と呼ぶ）がある。この事業は平成 4 年度現在, 全国155地区で実施されているが, その特徴としては, (1) 1 ha以上の区画を有する 圃場をおおむね $1 / 4$ 以上形成すること，(2)「経営 面積がおおむね 5 haを超える個別経営または生 産組織が受益地の扔おむね 4 分の 1 以上を経営対 象とすることを計画目標」としている点が指摘で きる1）。ただし，これを実施するためには従来以 上に換地作業が困難化し，合意形成が難しくなる 怖れもあるが，今後の担い手農家・組織の規模拡 大, 農業所得の増大, 生産費の低減等を実現させ るためには，こうした大区画圃場の形成が重要な 要素になる。

そこで本稿では，こうした大区画圃場整備事業 の実施可能性に関して, 秋田県平鹿郡大雄村 (剩 水（せせなぎ）地区]で実施された大区画圃場整 備事業を対象事例とし, 特に, 関係農家間で思い 切った換地が合意された要因を, 換地方法や換地 結果からみていくことにしたい。具体的には, 関 係農家に対して行ったアンケート調査結果や，阿 気地改良区および圃場整備事業の換地委員長に
対する聞き取り調査結果等に基づいて，事業の評 価とその関係要因，およびそれらの相互関係につ いて考察していく。

ところで，固場整備事業の合意形成に関して は, 従来から多く研究が行われており，それには 大泉一貫 ${ }^{2)}$, 長谷部正 ${ }^{3)}$ ，俞炳強 ${ }^{4}$ ，等のものを あげることができる。それらのなかでは，固場整 備事業の合意形成のためには, 経営規模, 固場分 散，事業に関する有用な情報提供，負担軽隇方法 の採用，関係機関の推進体制の工夫, リーダーの 存在等が重要な要因として指摘されている。ただ し,これらは換地の合意形成要因に限定し，焦点 を当てたものではない。

この固場整備事業の合意形成のなかでも，主に 換地の合意形成要因を考察したものには，「水田 の大区画化の合意形成と換地方式」5)や，「大区 画水田の整備と利用権の面的集積」6)等がある。 このうち前者は, 新潟県神林村の全村围場整備事 業と関連施設の総合整備事業を事例的に考察した ものである。そこでは合意形成要因として，(1)小 規模零細農家層から換地を行い, 小区画圃場を各 集落の近傍に設定して小規模農家層に配慮したこ と，(2)三角地や端歩地を村の役員が引き受けたこ と, (3)借地面積が減少する受け手農家に対して は，別途担い手育成対策を講じるようにしたこ と, 等が指摘されている。一方, 後者では利用権 の面的集積のための換地に言及しているが，まず 地区内の一部農家による集団（共同）的土地利用

*鳥取大学農学部 Faculty of Agriculture, Tottori University, Tottori, Japan (680)

Key Words：1) 大区画戋場整備，2) 換地，3) 合意形成要因 
を目的とした利用権の面的集積のための換地の場 合は, (1)強力なリーターーシップを有する人物の存 在, (2)経営能力の高い優れた経営者の存在が重要 で,また地区内の相対的に劣位な農地の団地的確 保に甘受することで面的集積を図ることが，合意 形成にとって必要な場合が多いことを指摘してい る。他方，個別的土地利用による利用権の面的集 積のための換地の場合については，貸し手が利用 権設定地の面的集積に同意するような動機づけの 仕組み（たとえば事業費負担の軽隇）の制度的必 要性を述べている。

ただしいうまでもなく，圑場整備事業自体の合 意形成要因は，換地のスムースな合意形成にも関 係している。たとえば，ある農家にとって換地自 体は必ずしも満足できる結果でなかったとして も，固場整備の実現により，換地結果のマイナス 便益を相殺して余りあるほどの大きな便益が得ら れるのであれば，換地は合意されよう。そこで本 稿では，換地自体だけでなく，固場整備事業全体 に関するこれら合意形成要因の重要性も踏まえた うえで，大区画圃場整備事業に関わる換地の合意 形成にとって重要な要因を考察することにした い。

なお，本稿では分析の視点として，以下の考え 方に依拠する。すなわち，事業内容が合意・実施 されるためには，どの関係農家も事業の実施前後 でその便益水準が低下せず，また単位面積あたり の増加便益額に関係農家間であまり格差が生じな いことが必要である7)。そのことは，既存研究で の換地の合意形成要因にみられたように，部分的 にマイナスの便益を被る農家や増加便益が相対的 に小さい農家に対する別途配虑が合意形成に慗っ ていることとも对応している。ただし土地改良事 業（圃場整㣁事業）の場合, 法的には2 $/ 3$ 以上の同 意があれば事業は実施可能であり，その点からす ると、こうした厳しい要件が満たされなくても事 業は実施できる。しかし，同意率が低いと事業の 実施が円滑には進まないため，ほとんどの場合， 同意率ができるだけ100\%に近づくことが重要で ある。したがって，関倸農家の便益水準の観点か ら大区画圃場整備事業の合意形成を考察すること には意義があるといってよい。

\section{II 調査対象地区と事業内容}

\section{1 調查対象地区の概要}

秋田県平鹿郡大雄村は，県南東部の横手盆地内 の水田単作地帯に位置しており，東側は横手市に 接し，西端には雄物川が流れている。当村の面積 は26.13 $\mathrm{km}^{2}, 人 口 は 6271 人 ~(1990$ 年国勢調查), 農 家戸数1061戸（1990年世界農林業センサス）で, 比較的小さな村だが，1戸あたり経営耕地面積は $164.0 \mathrm{a}$ (同上), 1 戸あたり生産農業所得は 178.2万円（1991年生産農業所得統計）と，農業 経営規模は比較的大きい。なお，当村は平坦地に 位置して起伏が少なく，また気温の日較差が大き いため, 米の単収 $(\mathrm{kg} / 10 \mathrm{a})$ も相当高く, 1987 年には687 kgを記録している。総じて，農業（特 に稲作）を行ううえでの条件に恵まれた地域とい うことができる。

事業対象となった剩水地区は当村の南西部に位 置し，地区内は平坦な地形で，南は雄物川町に接

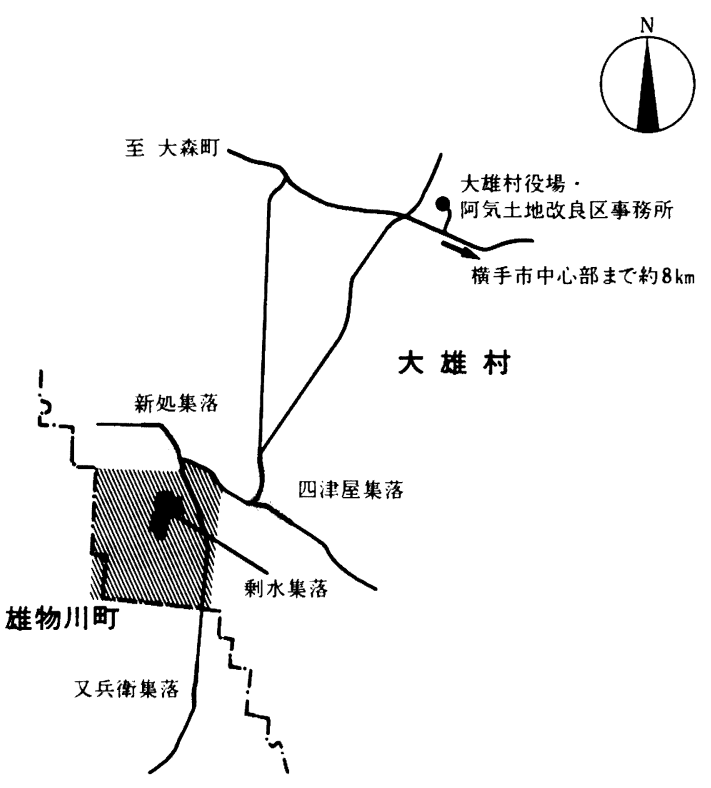

図 1 事業対象地区の位置

Fig. 1 The Map Around the Land Consolidation Project District 
している (図 1 参照, 事業対象地区は斜線が引か れた部分)。剩水地区自体は農家戸数12戸ほどの 小規模な集落だが，当圑場整備事業は（換地前後 の少なくともどちらかで当地区内に農地を所有す る）関係農家が40戸ほどあり，その多くが隣接す る新処集落 (4 戸) や四津屋集落 (15戸), さら には雄物川町の又兵衛集落等 ( 9 戸) に分散して いる。なお, 事業対象となった農地はすべて水田 である。

\section{2 事業実施までの動き}

剩水地区は阿気土地改良区に属しているが，村 内では比較的早く，1954年の秋から1955年の春に かけて 10 a 単位の区画整理が実施された。しかし それ以降, $10 \mathrm{a}$ 区画のままでは将来の営農展開を 考えるうえで問題があると感じられるようになっ た。そこで当地区では，1989年に「固場整備事業 を考える会」を発足させ，固場整備事業について 議論を始めたが, 当初は 30 a 区画を念頭に置いて いた。しかし高生産性大区画ほ場整備事業の情報 が入り, 従来の事業に比較して, 当事業の方が村 - 地元負担金割合が低くて有利なことから $(27.5 \% \rightarrow 20.0 \%)$, 将来的な展望も考えて, 1 ha区画も含んだ圃場整備に取り組むことになっ た。

そこで，土地改良区は1991年度の終わりにたた き台としての事業原案を関係農家に提示した。そ の段階ですでに，後述する 1 ha区画と 30 a区画の 圑場配置についての骨格が出来上っていた。事業 採択は1992年 4 月で, 総面積 $35.7 \mathrm{ha}$, 総事業費 2 億 9400 万円，負担割合は国50\%，県 $30 \%$ ，村 $10 \%$ ，地元 $10 \%$ である。なお，関係農家へ原案が 提示された後, 半年かけて事業実施に対する説得 活動が行われ，1992年 9 月に関係農家から事業実 施の同意を得た（同意率は $100 \%$ に達している）。 この圈場整備事業に当初反対であった農家も最終 的に同意した理由は，世帯主が後継者へ経営権を 委譲して農業者年金を受給するようになることに 関連して，後継者の意向が作用したためである。

ところで当地区では，この事業に付帯して「21 世紀型水田農業モデルほ場整備促進事業」(以 下，21世紀型事業と呼ぶ）を導入しており，対象
事業の年度事業費の $10 \%$ 相当額以内の金額が農業 生産集積促進費として土地改良区に交付され，従 来に比べて格段に安い地元負担額で事業が実施さ れることになっている（ただし目標年次において $50 \%$ を超える農業生産集積率を達成する必要があ る)。この21世紀型事業は1993年 3 月に採択され た。

\section{3 甬場整備事業の内容}

つぎに固場整備内容をみると，当事業は(1)区画 整理・拡大, (2)農道拡幅, (3)用排水路分離, (4)暗 渠排水敷設から構成されている。このうち区画整 理は，大区画（1 ha区画）戋場 19.6ha と標準区 画（30 a 区画）圃場 13.7haの造成が主内容で, 1 ha区画圃場が全体の $55 \%$ を占めており，事業 要件を大幅に上回っている（図 2 参照)。これに は，当地区が平坦地であることも大いに関係して いる。一方, 農道については幅員 $5.5 \mathrm{~m}$ の幹線・ 支線道路のほか, 作業効率を考慮して排水路側に も幅員 $3.5 \mathrm{~m}$ の作業用道路を設置したことが特徵 である。また従来の圃場は，用排水路兼用で暗渠 排水も整備されていなかったが，この事業によ $\eta$, 用水路 · 排水路の分離 - 整備と暗渠排水の整 備が実現した。なお, 娄場整備は 1 ha区画圃場 では1992年秋〜1993年春に，30 a 区画圃場は1993 年秋〜1994年春にかけて施工された。

以上のように,この事業によって当地区の圃場 条件は大きく改善されたが，21世紀型事業の併用 により事業費負担は 5 年据置きの 15 年償還で, 年 ・10 a あたり4000円台で済むと予想されている。 21 世紀型事業がない場合と比較すると, 約 1 万円 の低減になり，当地区にとっては費用負担上，大 きなメリットがある。なお21世紀型事業では，当 該地区の担い手農家等に農地を集積することが条 件となっているが, ここではその担い手農家とし て 3 戸が設定されている。この 3 戸は, 剩水地区 内に多く農地を所有しており，かつ農業後継者の いる農家である主1)。ところで，一般農家には世 帯主の高齡化，農業後継者不在等の実態があるた め, 今後21世紀型事業の導入によって担い手農家 3 戸へ農地を集積し, これらの担い手農家が当地 区農業の中心的役割を果たすことは関係農家間で 


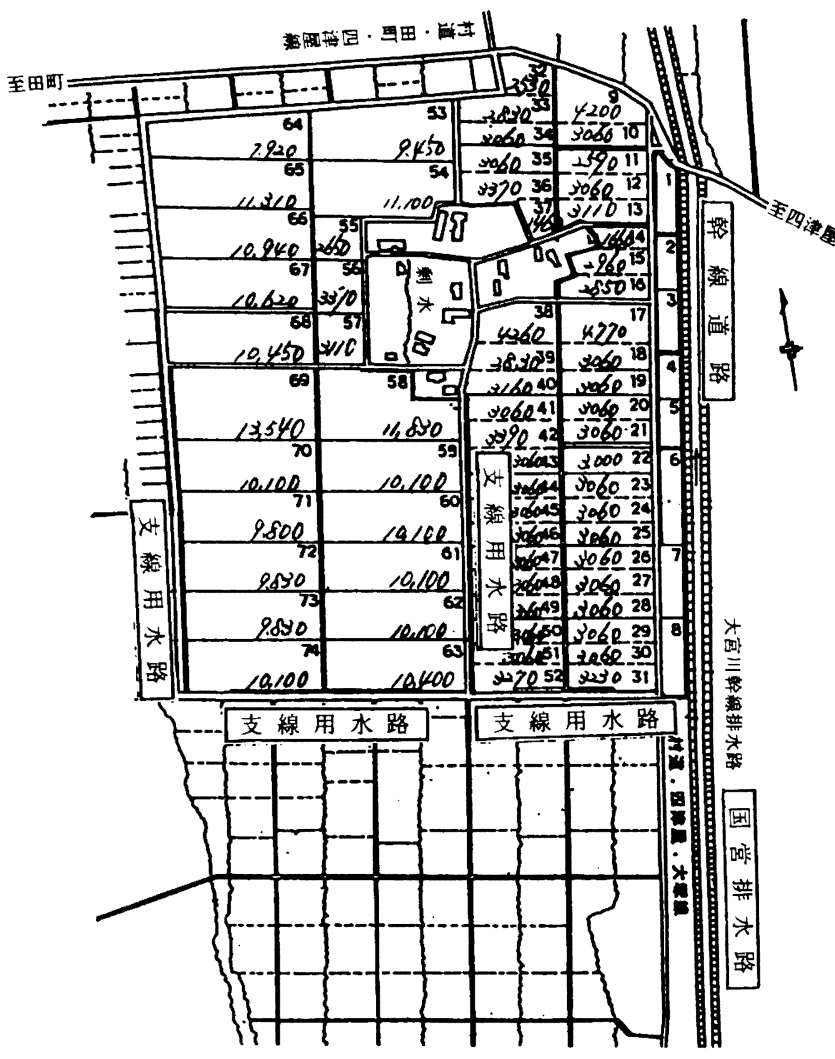

図 2 大区画圃場整備事業計画図

Fig.2 A Map of the Land Consolidation Project 出所：阿気土地改良区料

も認知されている。そこで，土地改良区として も，こうした実態や事業負担金が格段に安く済む ことで，一般農家の説得を行ってきた。

\section{4 換地方針・内容と同意プロセス}

この大区画圃場整備事業では, 従来の 10 a 区画 を 1 ha区画と 30 a 区画に再編することから，土 地改良区では現地換地ではなく，かなり思い切っ た換地方針を採用した。すなわち，1 ha固場 (図 2 の西側部分) の所有細分化を避けるため, (1)担い手農家をはじめとする面積規模の大きな農 家に 1 ha固場を配分して, (2)規模の小さな農家 は30a 固場（図 2 の東側部分）に換地し,さらに (3)当地区内での所有面積が 30 a に満たない農家 は, 原則として当地区外に, 他農家との交換分合
によって換地する，というものである。 なお，この方針に沿う換地原案は，土地 改良区の委託により, 秋田県土地改良事 業団体連合会の換地士が作成している。

この換地原案は1992年10月頃に完成 し，関係農家に提示された。換地委員会 には, 各集落から 4 名の代表者が出て検 討が行われ, 換地委員会での検討結果は 各集落ごとの会議に還元され, その結果 は換地委員会へ再び持ち寄られている。 このようなフィードバックを繰り返し， 多い月には10回程度会議を開催して, 1993年 3 月に換地内容に関する関係農家 の同意が得られた(仮換地)。なお，1994 年に確定測量を終了しており，1995年 3 月には本換地を済ませる予定である。

ただし検討過程では，まず各集落に近 い場所へ当該集落農家の農地を換地する という方針はスムースに合意されたが, その後の各農家の具体的な換地場所の確 定には手間取った。すなわち，上述した 基本原則ですべて換地が実施されたわけ ではなく，何度も換地案を練り直してい る。その過程では, 地区内外を問わなけ れば，どの農家にとっても所有農地の団 地化になるような配慮が払われたほか，

換地委員会の委員長（土地改良区の総 代）や副委員長 (事業の担い手農家)に全体合意 のために相対的に条件の悪い換地内容を受け入れ てもらった。また, 換地により地区外へ所有農地 が移る農家の地区外での団地化をはかるため, 事 業に関係していない農家 4 戸にも，農地の交換に 協力してもらっている。

図 3 は, こうして実際に関係農家間で合意され た換地内容を示したものだが，1 ha固場の多く は相対的に面積規模の大きな農家に換地されてい ることがわかる。これにより，280a を超える団 地煵場を所有することになった農家（S N 2) も ある。そして, 多くの農家では当地区内の所有地 が 1 ～ 2 団地に統合された。図 4 は围場整備実施 前の関係農家の農地所有状況を示したものだが, 図 3 と比較すれば明らかなように, 所有地が大幅 


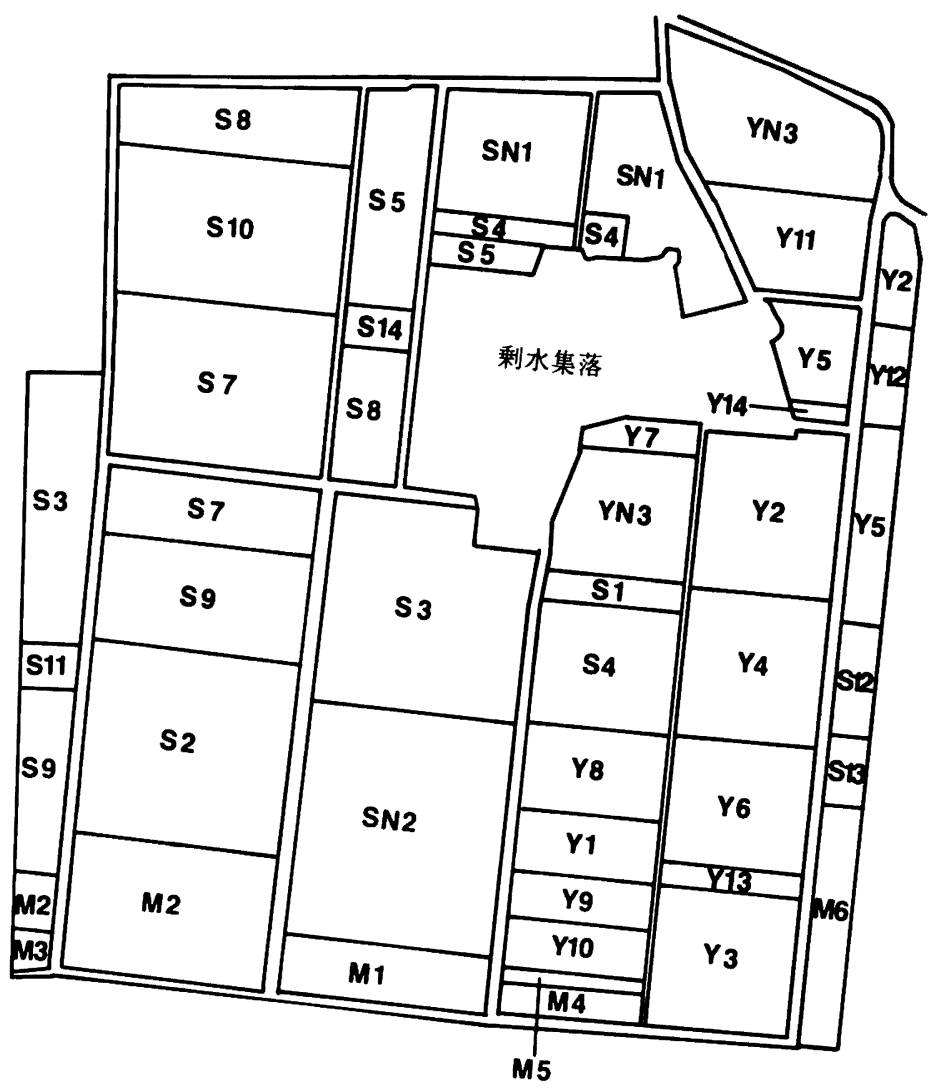

図 3 換地後の農地所有状況

Fig.3 The Map Illustrating the Location of Rice Paddy Fields Ownd by Each Farmer after the Replotting Disposition

注：困中の記号は辳家番号を意味するが、記号内のアルファペット（S、Y、M)は それぞれ以下の集落農家であることを示している。

$\mathrm{S}$ : 剩水集落、 $\mathrm{Y}$ : 四津屋菓落、 $\mathrm{M}$ : 又兵衛菓落およU゙田中集落、

また、S、Y、M以外にNの記号がついた厐家は、21世紀型事業の担い手鹿家

であるごとを意味している。

出所：阿気土地改良区资料(一筆地図)を加工して作成。

に移動したなかで，区画拡大が害現し，固場分散 もかなり解消されて, 従来よりも一層労働生産性 の高い水田経営の遂行可能な条件が醸成された。 なお，(3の方針により，換地過程で当地区に所有 地がなくなった農家（S 6,M 7, M 8,M 9) や，逆に換地後新たに当地区内に所有地が生じた 農家（S 14）もある。

III 事業評価と合意形成要因

\section{1 関係農家の事業評価}

つぎに，大区画圃場整備事業の実施に関する関 係農家の評価をみたい。表 1 は関係農家に対して 実施したアンケート調査の集計結果を示したもの である。調査は，換地対象農家40戸のうち36戸に 対して1994年 4 月に郵送法で行い，そのうち22戸 から回答を得た（回収率61.1\%)。

回表をみると，まず当事業の総合評価（Q1) 


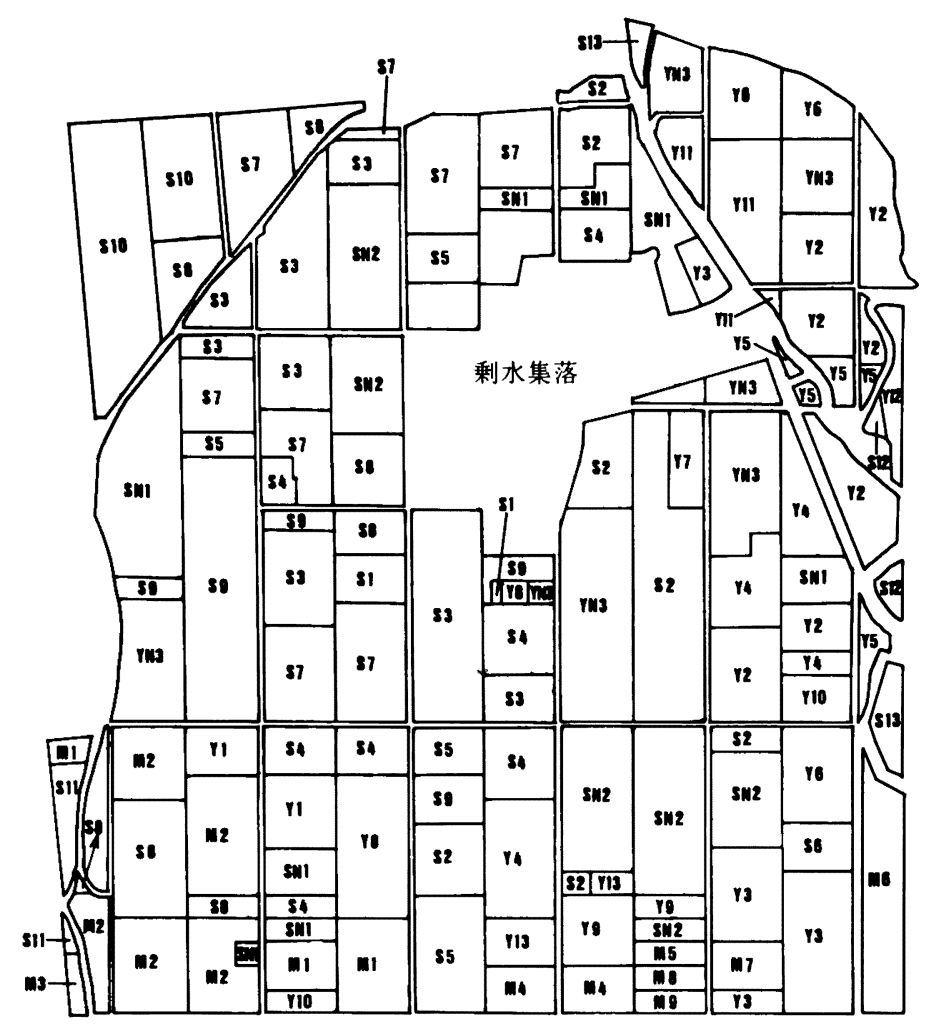

図4 換地前の農地所有状況

Fig.4 The Map Illustrating the Location of Rice Paddy Fields Ownd by Each Farmer before the Replotting Disposition 注：1）図中の記号は図 3 と同しである。

2）Y14鹿家の所有地は、従前圃場の一筆地図からは場所が正しく把暒でき なかったので、国中には栈せていない。

出所：阿気土地改良区料(一筆地図)を加工して作成。

は総じて高く，20戸 $(90.9 \%)$ が「(大変) よか った」と回答している。水田面積規模（Q2) は 分散が大きいが, 150 400 a 程度の農家が多い。 農業所得依存度（Q３）をみると，10９0\%の間 に幅広く分布しており，これも多様である。つぎ に，当事業の対象となった所有水田面積の割合 （Q 4) も多様で, 当事業への関係の程度は農家 によって相当異なることがわかる。

つぎに固場整備の必要性（Q５）は，17戸 (77.3\%) の農家が「(絶対) 必要であった」と回 答しており, 総合評価とともに必要性も高く認識 していたことがわかる。阿気土地改良区が剩水地 区に当該諸事業を導入したのも，当地区の意欲の 高さを評価したためであるが，この結果はそのこ
とを反映しているといえよう。また，思い切った 団地化に対する評価（Q6）をみると，16戸（a + b : 72.7\%）の農家が肯定的に評価しており, 「(大変) 覀かった」とする農家は 2 戸に過ぎな い。このような評価には, 当地区の土地条件も大 きく関係している。Q 7 をみると換地前後の土猿 条件注2) の変化をマイナスに評価する農家も少な くないが, 換地の際の水田評価では100 95ポイ ント程度の開差しかなく, 土地条件は均質に近 い。これらのことが思い切った換地・団地化を可 能にした一要因である。なお，Q7に関する土壤 条件変化のマイナス評価についても, 聞き取り調 查によれば，戋場整備期間中の悪天候により，1 ha区画圃場では表土が崩れて山積み状態に維持 
表 1 剩水地区高生産性大区画圃場整備事業等に関するアンケート調査集計結果

Table 1 Results of a Questionnarie Survey about the Land Consolidation Project

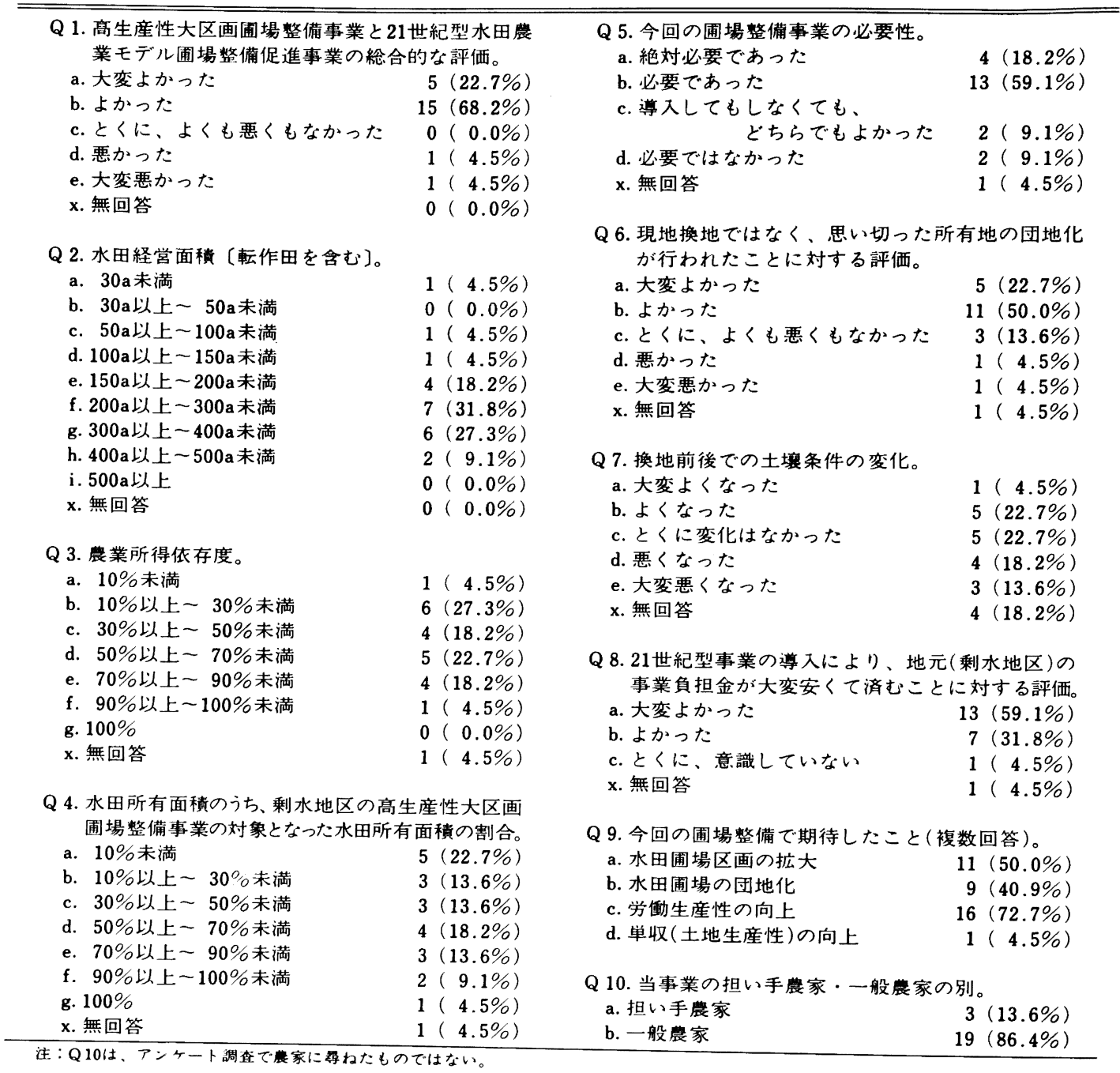

できなかったため，表土を围場に十分戻せなかっ たことが原因であり，換地による所有地の移動に 基づくものではない。また21世紀型事業の導入に よる負担金の大幅な軽減（Q 8) についても, 20 戸 $(90.9 \%)$ の農家が「(大変) よかった」と回 答しており，事業関係農家は総じて当該諸事業の 実施を積極的に評価していることがわかる。

一方, 固場整備事業に期待した項目 (Q9) と しては, 水田固場区画の拡大, 水田圃場の団地 化, 労働生産性の向上が中心で, 土地生産性の向
上を期待していた農家はほとんどみられないが， これは大区画戋場の形成という当事業の性格や， 当地区の単収水準が相当高いことから考えると, 当然の結果といえよう。

\section{2 事業評価と関連要因の相互関係}

つぎに，事業評価とその関連要因相互間の関係 を考察する。ここでは表 1 の質問項目のうち，Q $1 \sim \mathrm{Q} 9(\mathrm{a} \cdot \mathrm{b} \cdot \mathrm{c})$, および大区画圃場整備 事業の担い手農家・一般農家の別（Q10）の合計 
表 2 事業評価と関係要因相互間の順位相関係数

Table 2 Spearman's Rank Correlation Coefficients among Appreciation of the Project and the Related Factors

\begin{tabular}{|c|c|c|c|c|c|c|c|c|}
\hline & Q 1 & Q 2 & Q 3 & Q 4 & Q 5 & Q 6 & Q 7 & Q 8 \\
\hline Q 1 & 1.000 & -0.051 & -0.155 & 0.159 & $0.657^{* *}$ & $0.606^{* *}$ & $0.499^{*}$ & 0.265 \\
\hline Q 2 & -0.051 & 1.000 & $0.715^{* *}$ & 0.141 & -0.214 & 0.118 & 0.131 & 0.182 \\
\hline Q 3 & -0.155 & $0.715^{*}$ & 1.000 & 0.213 & -0.348 & 0.225 & -0.242 & 0.165 \\
\hline Q 4 & 0.159 & 0.141 & 0.213 & 1.000 & $0.453^{*}$ & 0.366 & 0.157 & 0.131 \\
\hline Q 5 & $0.657^{* *}$ & -0.214 & -0.348 & $0.453^{*}$ & 1.000 & $0.559^{*}$ & 0.351 & $0.446^{*}$ \\
\hline Q 6 & $0.606^{* *}$ & 0.118 & 0.225 & 0.366 & $0.559^{\circ}$ & 1.000 & 0.279 & $0.503^{*}$ \\
\hline Q 7 & $0.499^{*}$ & 0.131 & -0.242 & 0.157 & 0.351 & 0.279 & 1.000 & 0.130 \\
\hline Q 8 & 0.265 & 0.182 & 0.165 & 0.131 & $0.446^{*}$ & $0.503^{*}$ & 0.130 & 1.000 \\
\hline Q 9-a & $0.555^{\circ}$ & -0.209 & -0.206 & 0.325 & $0.584^{* *}$ & $0.605^{* *}$ & $0.430^{*}$ & 0.144 \\
\hline Q 9-b & $0.578^{* *}$ & -0.279 & -0.035 & 0.042 & $0.459^{*}$ & 0.359 & 0.101 & $0.464^{\circ}$ \\
\hline Q 9-c & $0.606^{* *}$ & 0.232 & -0.044 & 0.014 & $0.598^{* *}$ & 0.359 & $0.611^{*}$ & $0.427^{*}$ \\
\hline \multirow[t]{2}{*}{ Q 10} & $0.537^{*}$ & 0.033 & 0.147 & 0.186 & $0.436^{*}$ & 0.243 & 0.272 & 0.144 \\
\hline & Q 9-a & Q 9-b & Q 9-c & Q 10 & & & & \\
\hline Q 1 & $0.555^{*}$ & $0.578^{* *}$ & $0.606^{* *}$ & $0.537^{*}$ & & & & \\
\hline Q 2 & -0.209 & -0.279 & 0.232 & 0.033 & & & & \\
\hline Q 3 & -0.206 & -0.035 & -0.044 & 0.147 & & & & \\
\hline Q 4 & 0.325 & 0.042 & 0.014 & 0.186 & & & & \\
\hline Q 5 & $0.584^{* *}$ & $0.459^{*}$ & $0.598^{* *}$ & $0.436^{*}$ & & & & \\
\hline Q 6 & $0.605^{* *}$ & 0.359 & 0.359 & 0.243 & & & & \\
\hline Q 7 & $0.430^{\circ}$ & 0.101 & $0.611^{* *}$ & 0.272 & & & & \\
\hline Q 8 & 0.144 & $0.464^{*}$ & $0.427^{\circ}$ & 0.144 & & & & \\
\hline Q 9-a & 1.000 & $0.420^{*}$ & $0.531^{*}$ & $0.498^{*}$ & & & & \\
\hline Q 9-b & $0.420^{*}$ & 1.000 & $0.498^{*}$ & $0.531^{*}$ & & & & \\
\hline Q 9-c & $0.531^{*}$ & $0.498^{*}$ & 1.000 & $0.475^{*}$ & & & & \\
\hline Q 10 & $0.498^{*}$ & $0.531^{*}$ & $0.475^{*}$ & 1.000 & & & & \\
\hline
\end{tabular}

注：**は有意水劷 $1 \%$ 、*は $5 \%$ の下で統計的に有意。

12個の指標を取り上げて，その相互間の関係をみ ていくが，分析に用いる12個の指標はいずれも選 択肢項目が順序尺度として扱えるため,ここでは Spearmanの順位相関係数を適用することにした 8)注3)。なおこの場合, 各指標（質問項目）と も，農家の順位は a , b , c 一の順序で, 1 位一 18位までつけている注4)。

表 2 は, 順位相関係数とその検定結果を示して いるが，相関関係が認められた指標相互間の関係 からは，以下の諸点が特徴として指摘できる。

(1)まず事業の総合評価は，事業の必要性，思い 切った団地化の評価, 土壤条件の変化, 3 つの事 業効果 (水田圃場区画の拡大, 水田圃場の団地 化, 労㗢生産性の向上) に対する期待, 担い手農 家・一般農家の別，と相関がある。

(2)しかし，負担金の大幅軽滅に対する評価とは 相関が認められず, 当事業の評価は具体的な事業 成果に依拠している。ただし負担金の大幅軽隇に 対する評価自体は絶対的に高く，そのことによっ て事業評価が全農家にわたって全般的に高くなっ
たと考えられる。

(3)また，経営規模も事業の総合評価とは相関が 認められない。これは，負担金あるいは負担金の 軽隇額が単位面積あたりでみて一定であることに よると考えられる。

(4)事業の必要性は, 農業所得依存度, および 3 つの事業効果に対する期待と正の相関関係があ る。なお，この 3 つの事業効果に対する期待相互 間にも相関関係が認められるが，これらはいずれ も労働生産性の向上に関する要因という点で共通 している。

(5)思い切った団地化の評価は，事業の必要性， 区画拡大効果の期待のほか, 負担金大幅軽減の評 価とも相関があるが，聞き取り調査結果による と，事業の必要性が思い切った団地化の評価に慗 っている。また農家にとっては，良い圈場整備を できるだけ少ない負担額で実施できることが事業 導入の重要な評価基準となっているため, 負担金 の大幅軽減という経済的効果が，思い切った団地 化に伴う換地内容のマイナス便益を相殺する役割 
を果たしたと考えられる。

(6)水田圑場区画の拡大や労働生産性の向上を期 待していた農家ほど, 土壤条件の変化を相対的に プラスと評価する傾向があるが、これは部分的に は，こうした農家ほど，土壤条件自体をあまり重 要視していないという側面が反映されたものと考 えられる。実際，聞き取り調査結果からも，そう した回答を得た。

(7)事業の必要性と負担金の大幅軽減に対する評 価とは正の相関関係が認められ，また担い手農家 ほど事業の必要性を強く感じており，3つの事業 効果に対する期待も大きいが，これらは当然の結 果といえる。

\section{3 換地の合意形成要因}

以上, 換地方針, アンケート調査 の集計結果, 順位相関係数, 等から 判断すると，事業評価が総じて高 く，思い切った団地化が関係農家間 で合意された背景には，以下の要因 があったと考えられる。

(1)まず, 区画拡大, 団地化や労働 生産性向上に対する期待を背景とし て, 当地区内農家にとって今回の圃 場整備事業の必要性は高いものとし て評価されていたこと。そのこと が，思い切った換地処分の評価にも 結びついていた。

(2)当地区では土地条件にあまり差 がなく、こうした換地で利害が対立 する要素が比較的少なかったこと （またこうした土地条件格差は, 完 全ではないとしても，あとで金銭的 に調整される)。

(3)今回の換地では, 地区内外を問 わなければ,ほとんどの農家にとっ て所有農地の $1 \sim 2$ 団地化が実現 し，その点に限定すると，ほとんど の農家にプラスの便益がもたらされ たこと。

(4)今回の固場整備では, 大区画圃 場整備事業のほか21世紀型事業も導
入されたことにより，事業負担金が格段に安くて 済むが，そのことが事業の絶対的評価を高めたと 同時に，思い切った団地化に伴う換地内容のマイ ナス便益を相殺する役割も果たしたと考えられる こと。

(5)担い手農家は相対的に事業の評価水準の高い 傾向があるが，他方では換地で相対的に不利な条 件を受け入れた場合もあり，そのことが結果的に みて, 事業全体から得られた単位面積あたり増加 便益額を関係農家間で均等化する方向への作用を 部分的ではあるがもたらしたと考えられること。

(6したがって，換地を単独で評価した場合に は, マイナスの便益を享受した農家もあると考え られるが, 期待される事業効果や格段に安い事業

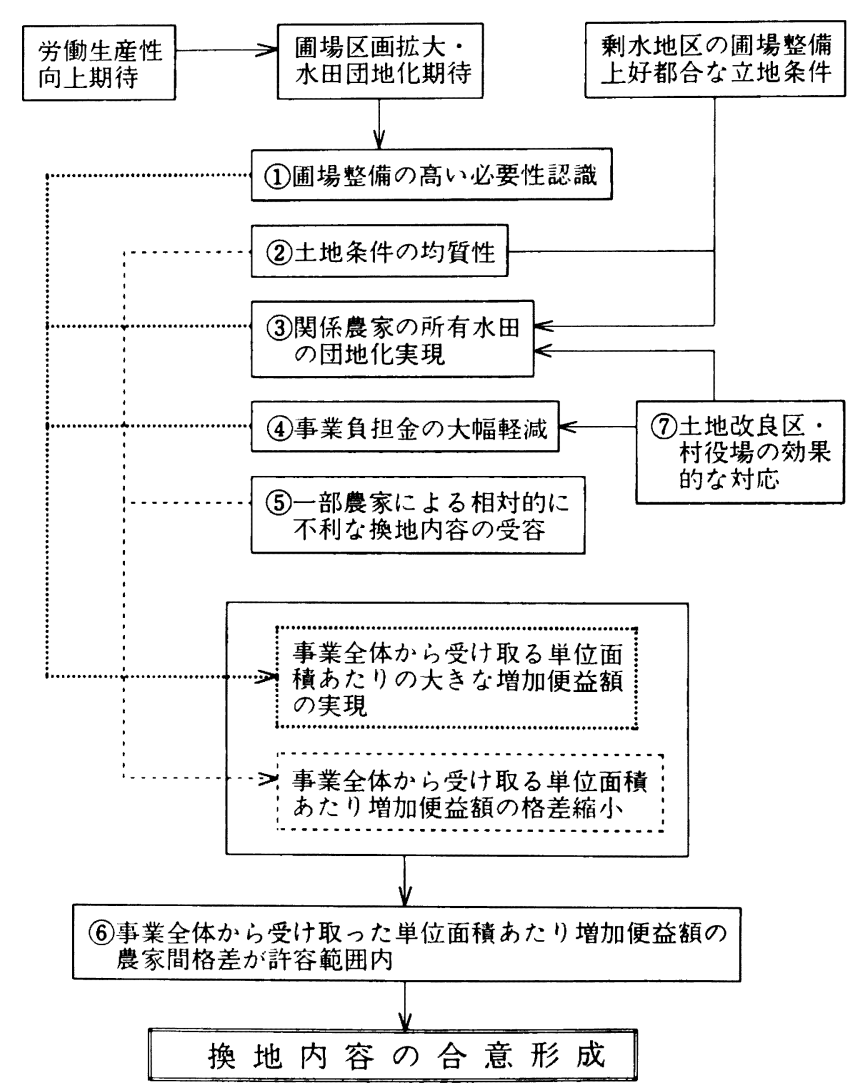

図 5 換地内容の合意形成とその関連要因との関係

Fig.5 The Relation among the Agreement on the Replotting Disposition and the Factors that have Affected It

注：1）図中の要因番号は本文中(換地の合意形成要因の項)のものと对応している。 2) 图中の線で矢印のないものは、因果関係を表わしていないことを意味している。 
負担金のメリットに比較すれば，その程度は相対 的に小さく, 単位面積あたり増加便益額に合意形 成を損なうほどの関係農家間格差が生じなかった といえる注5)。

(7)上のほかにも，適当な補助事業の選定や選 定した事業を進めるうえで, 阿気土地改良区や大 雄村役場が効果的な対応をとったことも無視でき ない。特に土地改良区が関保農家間で協議する際 のたたき台となる計画原案や換地原案を適当な時 期に提示して、リーダーシップをとりながら事業 を進めていったことは, 合意形成の円滑化にとっ てプラスに作用した。

以上の関係を図示すると，図 5 の通りである。 また, 既存研究成果との関連でみると, 部分的に マイナス便益を被る農家あるいは増加便益が相対 的に小さい農家に対する別途配虑, 換地役員の譫 歩, 事業実施前の圃場分散, 事業に関する有用な 情報提供, 負担軽減方法の採用, 関係機関の積極 的な推進体制に基づいた効果的な機能発揮等の点 で当地区の特徽を指摘でき，これらの要因が围場 整備事業や換地内容の合意形成を容易化したと解 釈できる。

\section{IV 総 括}

以上，本稿では大区画圃場整備事業を対象とし て, 換地の合意形成要因について考察した。利水 地区に扔引る大区画圃場整備事業では, 事業要件 を大きく上回る受益面積の $55 \%$ \% $1 \mathrm{ha}$ 区画とし， 思い切った換地が合意され，また事業の総合評価 も全体的に高いが，それは関係農家のほとんどに とって事業実施から得られる便益が大きく，農家 間の単位面積あたり増加便益額の格差が問題とな らない範囲内に留まったことが基本的な理由であ ったといえる。またそこには，関係農家の主体的 条件 (事業の必要性に対する意識, 事業効果への 期待), 従来に比べて格段に安い事業負担金, 土 地条件の均質性, さらにはほとんどの農家にとっ $\tau 1$ - 2 団地化になった適切な換地作業, 等の要 因が作用している。

将来的に, こうした大区画圃場整備の重要性は
一層強まるが, 当地区の場合は, 換地の合意形成 を容易にする条件が多く備わっていた。したがっ $\tau$, 他地区で当地区と同程度の割合の大区画圃場 を形成する場合には，当地区よりも換地の合意形 成が困難なことが予想される点には留意を要す る。

【付記】本稿は, 平成 5 年度文部省科学研究費補 助金 (奨励研究(A) 研究課題名「地域農業計画の 実行可能性向上に関する研究」）に基づく研究成 果を基礎としてまとめたものである。

\section{注}

注 1）ただしこの3 戸以外にも，関係農家のなかには 当地区以外に多く経営耕地を有している農家もあ ク，そのなかには当地区外で規模拡大を志向して いる農家もある。

注 2）土壤条件はいうまでもなく土地条件の一部であ ク,ここでいう土地条件では土埻のほか, 傾斜 度, 非農業的用途への転用可能性, 日照時問，用 排水，等の要因を念頭に置いている。

注 3）ここでは，この12個の指標に関して無回答のな い18農家の回答結果を順位相関俰数の計算に用い ている。

注 4) 順位相関係数の計算では, 同順位のサンプルに 対してそのすべてに平均順位をつける。たとえ ば， Q 2 のにには 4 戸の農家が該当しているが, この場合, $\mathrm{a} \sim \mathrm{d}$ に該当する農家が 3 戸あるの で，eに該当する農家は $4 \sim 7$ 位を占めることに なる。そこで, この 4 つのサンブルとも， $(4+5$ $+6+7), 4=5.5$ 位となる。

注 5) なお，アンケート調査結果 $(Q 1)$ からわか るように，事業について「(大変)悪かった」と評 価している農家も2 戸ほどみられるが, そう評価 したのは合意形成以前からで，事業原案提示当初 には合意形成を妨げる可能性があったと考えられ る。そういうなかで合意形成が実現できたのは, 前述した後継者の意向の反映のためであろう。ま た，結果として合意形成されたにもかかわらず, アンケート調査でマイナス評価を下しているの は, アンケート調查への回答者が世带主であった ため, 事業原案提示当時の反対意見がそのまま示 されたものと考えられる。 


\section{文 献}

1）農水省構造改善局建設部監修（1993）：農業農村整 備の全容 解説編一平成 4 年度改定版一、公共事 業通信社, pp102 103

2 ）大泉一貫（1989）：農業経営の組織と管理, 農林統 計協会, pp191 205

3 ）長谷部正（1990）：圃場整備同意率に影響を及ほす 経済的要因の計量分析, 農業経済研究, Vol.62, No.1, pp12 21
4 ）俞炳強（1993）：基盤整備と地域的合意形成，農林 統計協会

5 ）里村孝一（1992）：水田の大区画化の合意形成と換 地方式一新潟県神林村における圆場整哄を事例に 一, 北陸農試農業経営研究資料, No. $40, \mathrm{pp} 1 \sim 14$

6 ）佐藤洋平（1989）：大区画水田の整備と利用権の面 的集積, 農業土木学会誌, Vol.57, No.3, pp35一 42

7 ) 頼 平 (1976)：共同組織と営農団地, 農業計算学 研究, Vol.9, pp27 -38

At present, one of the main subjects of land consolidation project is to widen the area of a paddy-field parcel and improve labor productivity. Typically, a project for performing such an objective is the "Land consolidation project for cost reduction in rice paddy fields". One of the conditions of this project is to divide parcels of paddy fields whose area is 1 ha or more, by four or more. But in order to accomplish such a condition, reaching an agreement on the replotting disposition becomes more difficult. So in this paper,the author has considered the factors which have made it easy for farmers to reach an agreement on the replotting disposition based on the project in the Sesenagi distriot in Taiyu-village, located on Akita prefecture as a case study. As a result, the following points have become clear:

(1)First, the farmers in the district have recognized that the necessity of the project is high.

(2)In the district, there are not significant differences in the field conditions, so there have been few factors preventing the farmers from reaching an agreement.

(3)In this case, the replotting disposition has resulted in one or two adjoining plots for most of the farmers, if the place in the district does not matter.

(4)In the district, another grant-in-aid project has been introduced whereby the charge for the land consolidation became very cheap for each farmer.

(5)There is a tendency that the level of appreciation for the project of the farmers, who are permitted to enlarge the scale of their farm in the district, is relatively high. However, on the other hand, equalization of the additional benefit per 10a received by each farmer may have also contributed partly to this.

(6)In considering the whole project, it can be said that it has not resulted in differences of the additional benefit per 10a received by each farmer as much as they have not been able to reach an agreement, as the expected effects of the projects is large and the charge they have to bear is very cheap. Consequently, it can be said that the farmers have been able to reach an agreement.

Key Words : 1) Land Consolidation for Making Large Land Parcels, 2) Replotting Disposition,

3) Factors That Affect the Agreement on the Replotting Disposition. 